\title{
OPEN Listeria monocytogenes sensitivity to antimicrobial treatments depends on cell origin
}

\author{
Chiara Montanari ${ }^{1,2}$, Giulia Tabanelli, ${ }^{1,2}$, Federica Barbieri ${ }^{1}$, Diego Mora ${ }^{3}$, Robin Duncan ${ }^{3}$, \\ Fausto Gardini ${ }^{1,2}$ \& Stefania Arioli ${ }^{3 凶}$
}

In this study we investigated how cell origin could affect the efficacy of an antimicrobial treatment (mild heating combined with terpenoids) in Listeria monocytogenes Scott A, considering cells from: 1 . single colony, 2. glycerol stock, 3 . cold adapted culture, and 4. fresh culture in stationary phase. After treatment, culturability on BHI medium and viability assessed by flow cytometry were evaluated. Our results showed that the cell origin significantly impacted viability and culturability of L. monocytogenes towards antimicrobial treatment. The mild heat treatment combined or not with terpenoids mainly affected culturability rather than viability, although the culturability of cells from single colony was less impacted. Therefore, to mimic the worst scenario, these latter were selected to contaminate Gorgonzola rind and roast beef slices and we evaluated the ability of $L$. monocytogenes cells to recover their culturability (on ALOA agar medium) and to growth on the food matrix stored at $4^{\circ} \mathrm{C}$ for 7 days. Our results suggest that only Gorgonzola rind allowed a partial recovery of the culturability of cells previously heated in presence or not of terpens. In conclusion, we found a connection between the cell history and sensitivity toward an antimicrobial treatment, underlying the importance to standardize the experimental procedures (starting from the cells to be used in the assay) in the assessment of cell sensitivity to a specific treatment. Finally, our study clearly indicated that VBNC cells can resuscitate under favorable conditions on a food matrix, becoming a threat for consumer's health.

Listeria monocytogenes is a ubiquitous bacterium responsible for a disease (listeriosis) which is among the major foodborne illnesses characterized by a high case-fatality rate (approximately from 20 to 30\%). Its wide environmental distribution, resistance to low $\mathrm{pH}$ and $\mathrm{NaCl}$ concentration, facultatively anaerobic metabolism and psychrotrophicity make this species one of the greater challenges for food industry ${ }^{1}$. Due to these characteristics, the risk of listeriosis is high in ready-to-eat foods (meat and dairy products) but relevant outbreaks has been associated also to fruit and vegetables (cantaloupe, celery, mung bean sprouts, stone fruits) ${ }^{2}$. In many cases, the control of this microorganism relies on thermal processing of foods. Temperatures above $50{ }^{\circ} \mathrm{C}$ are needed for thermal death of $L$. monocytogenes cells. However, the inactivation kinetics can be very different, with $\mathrm{D}_{65}$ ranging from 0.2 to 2 min according to ANSES $(2012)^{3}$. Recently, revision of literature confirmed this variability in $\mathrm{D}$-value ${ }^{4}$, indicating that it may change in relation to temperature suggesting non-linear inactivation dynamics ${ }^{5}$. On the other hand, the application of high temperature may have negative effect on the sensory, nutritional, and textural characteristics of food that may be contaminated by L. monocytogenes. Therefor strategies based on synergistic effects of thermal treatment with antimicrobials are exploited to avoid excessive heat damages. In this perspective, the use of essential oils or their constituents (added below their minimum inhibitory concentration) can be a suitable approach: the presence of thymol, carvacrol, citral, (E)-2-hexenal, vanillin is reported to increase the inactivation rate of thermal treatments ${ }^{6-11}$, due to cumulative antimicrobial effects of heat and aroma compounds. These latter are enhanced by the increase of vapour pressure caused by heat which, in turn, increases their solubility in cell membrane, the first target of their antimicrobial activity ${ }^{12,13}$. Inactivation results obtained in heat treatment experiments are subjected to a variability which depends on several factors. In addition to the process parameters, a relevant part of this variability is associated to the different responses of the treated cells.

\footnotetext{
${ }^{1}$ Department of Agricultural and Food Sciences, University of Bologna, Bologna, Italy. ${ }^{2}$ Interdepartmental Center for Industrial Agri-Food Research, University of Bologna, Bologna, Italy. ${ }^{3}$ Department of Food, Environmental and Nutritional Sciences (DeFENS), Università Degli Studi di Milano, Via Celoria 2, 20133 Milan, Italy. ${ }^{\square}$ email: stefania.arioli@unimi.it
} 
1 - from colony to BHI broth

2 - from frozen stock to BHI broth
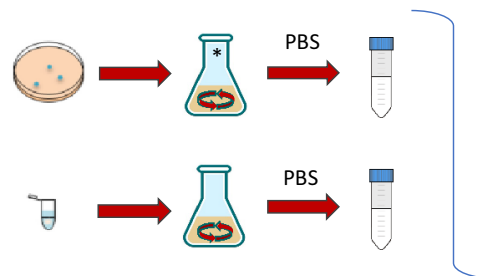

3- cold-adapted cells to BHI broth
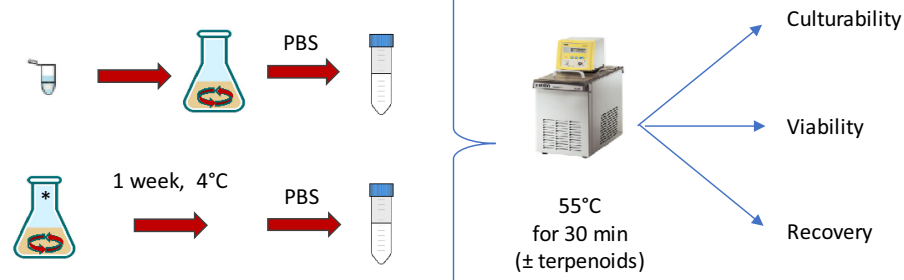

4 - from broth to broth

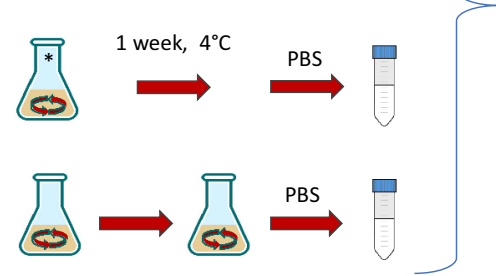

(terpenoids)

Figure 1. Schematic representation of four cell origin used in this study. Origin 1: from single colony to BHI broth; origin 2: from frozen stock to BHI broth; origin 3: cells derived from the condition 1 and then coldadapted $\left(1\right.$ week at $\left.4{ }^{\circ} \mathrm{C}\right)$; origin 4 : from culture in early stationary phase to BHI broth.

Variation can characterize strains of different species, strains of the same species or the same microorganism grown under different environmental conditions ${ }^{14}$.

Laboratory tests on stress responses of microorganisms of concern in foods, such as thermal treated $L$. monocytogenes, are often carried out using liquid batch cultures, which are assumed to be phenotypically homogeneous. This assumption has recently been debated by Kragh et al. ${ }^{15}$ which demonstrated the relationship between the method of inoculation of liquid batch cultures (Pseudomonas aeruginosa) and antibiotic tolerance (tobramycin). The effect of the physiological state of a broth culture (cells in exponential phase or in stationary phase) has already been discussed ${ }^{16}$ being cells in exponential phase more susceptible to heat ${ }^{17}$. However, Kragh et al. ${ }^{15}$ posed their attention on the history of the cells used for the preparation of the liquid inoculum and observed that second generation cultures (obtained even after a 1000-fold dilution) were able to maintain phenotypic characteristics deriving from the status of the initial pre-cultures (colony, liquid, frozen stock) keeping a sort of memory, mainly related to exopolysaccharides production and ability to form aggregates. Other studies reported the influence of the age and conditions of inoculum on the frequency Escherichia coli cells able to survive antibiotic treatment ${ }^{18}$. In Staphylococcus aureus the growth mode and the growth stage strongly influenced the surfaceome, and consequently the cell sensitivity to levofloxacin ${ }^{19}$. In L. monocytogenes the effects of the growth temperature and growth phase on the cell inactivation after high pressure processing in milk were evaluated ${ }^{20}$.

In the current work, cells of $L$. monocytogenes of 4 different origins were subjected to a mild thermal treatment $\left(55^{\circ} \mathrm{C}\right)$ in the presence or in the absence of two terpenoids with antimicrobial activity (thymol and carvacrol). The effect of the treatment was evaluated by monitoring the culturability (by plate counting) and the viability (by flow cytometry) of the treated cells. Then, the growth performances of the survived cells were modeled with the Gompertz equation. The variation of the resulting parameter $\lambda$ (lag phase duration) was further analysed for evaluating the variability of the responses in relation to the treatment and to the cell history. The cells deriving from the condition able to guarantee the higher recovery after heat treatments were chosen to perform a trial in food systems, namely Gorgonzola rind and roast beef slices.

\section{Results and discussion}

Effects of treatments on viability and culturability of $L$. monocytogenes. To examine the impact of cell origin on the efficacy of mild heat treatment combined or not with terpenoids, L. monocytogenes cells were cultivated in different conditions (Fig. 1). After growth, cells diluted in PBS were subjected to the antimicrobial treatment, in presence or not of terpenoids at sublethal concentrations, based on the previous determination of minimum inhibitory concentration (MIC) ${ }^{6}$. The results obtained are summarized in Table 1. In control cells no significative differences in terms of Active Fluorescent Unit (AFU)/ml and CFU/ml (viability and culturability, respectively) were observed, confirming an initial inoculum of approx. $6 \log$ AFU or CFU/ml.

Based on flow cytometry data in non-treated cell suspensions we did not highlight relevant differences in terms of distribution of the 3 subpopulations (AFU, damaged and non-Active Fluorescent Unit non-AFU), indicating that the cell origin did not affect the viability of the cell, even after one week of storage at $4{ }^{\circ} \mathrm{C}$. After the thermal treatment at $55^{\circ} \mathrm{C}$, the viability was not significantly affected in all tested condition. By contrast, the culturability was severely compromised. In fact, a decrease of culturability of 3.14, 2.66 and $2.57 \log \mathrm{cfu} / \mathrm{ml}$ was observed for cell origin 2, 3 and 4, respectively (Table 1). Conversely, cells derived from condition 1 (from colony) were the less affected by the thermal treatment, with a decrease of culturability of about $1.90 \mathrm{log} \mathrm{cfu} /$ $\mathrm{ml}$. The thermal treatment in presence of thymol and carvacrol increased the discrepancy between viability and culturability. Indeed, the viability decreased from 0.36 up to $1.34 \log$ AFU/ml for cells from origin 2, 3 and 4 . Conversely, cells from condition 1 was not significantly affected by the treatment. In parallel, the culturability was almost or completely abolished. Indeed, the culturability of cold-adapted cells (condition 3) was about $1.97 \mathrm{log}$ 


\begin{tabular}{|c|c|c|c|c|c|c|c|c|c|c|c|c|c|c|c|c|c|c|}
\hline \multirow[b]{3}{*}{ Cell origin } & \multicolumn{6}{|c|}{ Control (untreated cells) } & \multicolumn{6}{|l|}{$55^{\circ} \mathrm{C}$} & \multicolumn{6}{|l|}{$55^{\circ} \mathrm{C} \mathrm{TC}$} \\
\hline & \multirow{2}{*}{$\begin{array}{l}\text { Plate counting } \\
\log \mathrm{CFU} / \mathrm{ml}\end{array}$} & \multicolumn{4}{|c|}{ Flow cytometry" } & \multirow{2}{*}{$\begin{array}{l}\text { Growth } \\
37^{7} \mathrm{C}^{\mathrm{b}} \%\end{array}$} & \multirow{2}{*}{$\begin{array}{l}\text { Plate counting } \\
\log \mathrm{CFU} / \mathrm{ml}\end{array}$} & \multicolumn{4}{|c|}{ Flow cytometry } & \multirow{2}{*}{$\begin{array}{l}\text { Growth } \\
37^{7} \mathrm{C}^{\mathrm{C}} \%\end{array}$} & \multirow{2}{*}{$\begin{array}{l}\text { Plate counting } \\
\log \mathrm{CFU} / \mathrm{ml}\end{array}$} & \multicolumn{4}{|c|}{ Flow cytometry } & \multirow{2}{*}{$\begin{array}{l}\text { Growth } \\
37^{\circ} \mathrm{C}^{\mathrm{b}} \%\end{array}$} \\
\hline & & $\log \mathrm{AFU} / \mathrm{ml}^{\mathrm{c}}$ & Alive \% & Injured \% & Dead \% & & & $\log \mathrm{AFU} / \mathrm{ml}$ & Alive \% & Injured \% & Dead \% & & & $\log \mathrm{AFU} / \mathrm{ml}$ & Alive \% & Injured \% & Dead \% & \\
\hline 1 & $6.06 a( \pm 0.24)$ & $5.99 \mathrm{a}( \pm 0.07)$ & 97.42 & 1.22 & 1.36 & 100 & $4.12 \mathrm{~b}( \pm 0.35)$ & $5.96 \mathrm{a}( \pm 0.05)$ & 93.10 & 1.84 & 5.06 & 100 & $3.08 c( \pm 0.42)$ & $5.84 \mathrm{a}( \pm 0.22)$ & 75.79 & 6.96 & 17.25 & 100 \\
\hline 2 & $6.03 a( \pm 0.07)$ & $6.11 \mathrm{a}( \pm 0.07)$ & 98.52 & 1.06 & 0.42 & 100 & $2.89 \mathrm{~b}( \pm 0.37)$ & $5.84 \mathrm{a}( \pm 0.19)$ & 76.69 & 5.87 & 17.43 & 79 & $<1$ & $4.77 \mathrm{c}( \pm 1.07)$ & 18.33 & 18.05 & 63.62 & 0 \\
\hline 3 & $6.08 \mathrm{a}( \pm 0.16)$ & $5.89 \mathrm{a}( \pm 0.27)$ & 96.70 & 1.11 & 2.18 & 100 & $3.42 \mathrm{~b}( \pm 0.33)$ & $5.78 \mathrm{a}( \pm 0.21)$ & 78.92 & 5.08 & 16.00 & 100 & $1.97 \mathrm{c}( \pm 0.67)$ & $5.16 \mathrm{~d}( \pm 0.40)$ & 33.52 & 14.82 & 51.66 & 43 \\
\hline 4 & $6.07 \mathrm{a}( \pm 0.25)$ & $5.94 \mathrm{a}( \pm 0.07)$ & 98.29 & 1.07 & 0.65 & 100 & $3.50 \mathrm{~b}( \pm 0.49)$ & $5.84 \mathrm{a}( \pm 0.10)$ & 95.63 & 1.76 & 2.64 & 50 & $<1$ & $5.58 c( \pm 0.18)$ & 83.83 & 7.79 & 8.39 & 11 \\
\hline
\end{tabular}

Table 1. Viability, culturability, and recovery in BHI broth of L. monocytogenes cells after mild heat treatment combined with terpens. ${ }^{a}$ Data are reported as total cells counted clustered as AFU (considered as alive cells), injured and non-AFU (considered as dead cells), expressed as percentages of the total cell number. For each inoculum, significant differences in culturability and viability between samples according to ANOVA are indicated by lowercase letters. ${ }^{b}$ Expressed as percentage of growth after the different treatments in the 28 repetitions for each condition.

$\mathrm{cfu} / \mathrm{ml}$ and below the detection limit $(<1 \log \mathrm{CFU} / \mathrm{ml})$ in conditions 2 and 4 . Conversely, the culturability of cells derived from colony to broth (condition 1) was less affected compared to the other conditions ( $3.08 \log \mathrm{CFU} / \mathrm{ml}$ ).

The synergistic effect between mild thermal treatment and antimicrobials has already been demonstrated for several microorganisms and conditions. Concerning L. monocytogenes, a relevant reduction of the treatment time required to obtain the same cell inactivation has already been reported in the presence of thymol, carvacrol, citral and (E)-2-hexenal ${ }^{6,11}$ and the synergy between essential oils and thermal treatment on foodborne pathogens has been recently reviewed by Gurtler et al. ${ }^{12}$. In first instance, the results obtained in these trials demonstrated that L. monocytogenes cells grown in aerobic conditions (stirred in a flask at $150 \mathrm{rpm}$ ) had reduced susceptibility than those grown in static conditions ${ }^{6}$, underlying the importance of the cell cultivation on the effectiveness of antimicrobial treatments. On the other hand, relevant differences in growth and survival performances of $L$. monocytogenes in relation to presence/absence of oxygen are well known ${ }^{21,22}$. In addition, as observed by Kragh et al. ${ }^{15}$, it is often assumed that a liquid batch culture contains phenotypically homogenous cells. However, these authors demonstrated that the inoculation method (i.e. cell history) has a relevant effect on the phenotypes of the resulting population. They demonstrated also that some characteristics (in the specific case the frequency of aggregation of Pseudomonas aeruginosa) of the cultures first seeded can be inherited in second generation cultures modifying responses to stress such as the presence of antibiotics.

In any case, the discrepancies between viability and culturability expressed as log CFU/ml raise the question of the viable but not culturable cells (VBNC) that in some cases consist in several log cells/ml. As stressed by Donnelly and Diez-Gonzalez ${ }^{23}$, improvement in testing methods for L. monocytogenes are needed to ensure an adequate sensitivity of detection for identifying and control the presence of this pathogen. Particularly, a better understanding of factors affecting the recovery and growth of VBNC cells is needed to determine the real effect of an antimicrobial treatment. Indeed, the VBNC state may be reversible ("resuscitation") and this condition is a concern when it involves storage of food material ${ }^{23}$.

Studies regarding the efficacy of inactivation methods on L. monocytogenes reported similar results that raised the same issues. For example, Alessandria et al. ${ }^{24}$ observed that after a treatment with cold atmospheric pressure plasma (APP) most of the culturable cells were inactivated but, when inoculated in BHI medium (therefore removing the environmental stress), some of them were able to regrow.

Although it is still matter of discussion if this regrowth is the result of a true resuscitation phenomenon or it is rather due to few residual culturable cells ${ }^{25}$, these observations highlight the need to integrate culturedependent and culture-independent approaches to monitor this pathogen, since conventional culture methods can overestimate the efficacy of the treatments performed.

The same considerations were reported by Noll et al. ${ }^{26}$, whose study evidenced that L. monocytogenes adapted to antimicrobial agents (in that case benzalkonium chloride) were viable and metabolically active according to FCM analyses but not detectable by standard cultivation techniques, indicating the occurrence of VBNC cells. $\mathrm{Gu}$ et al. ${ }^{27}$ investigated the susceptibility of some foodborne pathogens (including L. monocytogenes) to sanitizers such as free chlorine and peracetic acid. They hypothesized the induction of a VBNC state, already reported in literature for these chemicals ${ }^{28}$, because of the discrepancy between the inability to detect cells by plating and the results of PMA-qPCR and laser confocal microscopy, that evidenced large amounts of DNA from theoretically viable bacterial cells. However, the conditions adopted in that study did not allow resuscitation of this population in vitro, but a possible recovery in vivo cannot be excluded, raising alarming threats for food safety.

Effects of antimicrobial treatments and cell origin on recovery ability and growth kinetics. To test whether the cell origin could influence the ability of the cells to recover after antimicrobial treatment, stressed cells were inoculated in a 96-well plate (for a total of 28 wells/repetitions for each condition) for $48 \mathrm{~h}$ at $37^{\circ} \mathrm{C}$. The recovery was expressed as percentage of wells displaying growth on the total of inoculated wells (Table 1). As expected, $100 \%$ of the wells inoculated with non-treated cells of $L$. monocytogenes displayed growth, regardless of the cell origin. Concerning the ability to recover after the treatment at $55^{\circ} \mathrm{C}$, all cells were able to recover but to different extent. Only cells from condition 1 and 3 displayed growth in $100 \%$ of the inoculated wells. Conversely, less efficient was the recovery of cells from condition 2 and 4, with percentages assessed at 79 and 50\%, respectively. When cells were subjected to the thermal treatment combined with terpenoids, the recovery capability was strongly impacted with an evident influence of the cell history. Cells from condition 2 


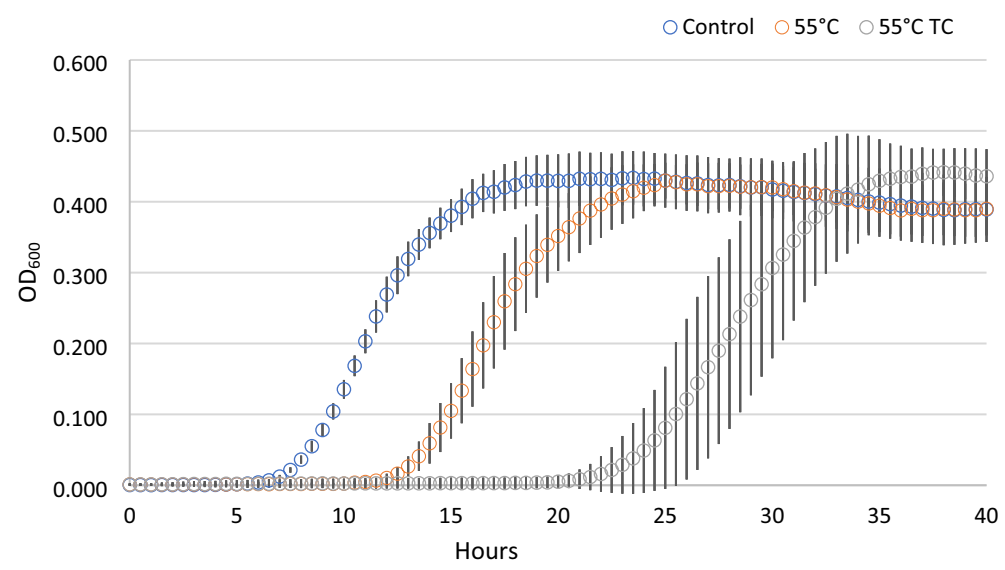

Figure 2. Growth curves of cells derived from condition 1, after antimicrobial treatments. Each time point is the mean of 28 replicates. For each point standard deviation is reported.

were not able to recover after treatment. Conversely, the recovery of cells from conditions 3 and 4 was 43 and $11 \%$, respectively. Instead, all wells inoculated with cells derived from condition 1 displayed cells growth. These differences can be explained by the culturability of treated cells (expressed as log cfu/ml). In fact, in the sample treated at $55^{\circ} \mathrm{C}$, the dilution used for the inoculation of wells (1:100) determined a mean inoculum of culturable cells of about $1 \log \mathrm{cfu} / \mathrm{ml}$ or even less (e.g. the case of cells from condition 2 after treatment at $55^{\circ} \mathrm{C}$; all cases after the mild heat treatment combined with terpenoids). The variability associated with these low inoculums could explain the presence of wells with no visible growth. By contrast, considering the sample thermally treated in the presence of terpenoids, the growth percentage did not reflect the associated culturability. The growth observed could be due to unculturable cells which however resulted alive according to the FCM protocol. This consideration opens the question of the fate of these cells over time.

In parallel to the recovery ability, we investigated the kinetic parameters of the treated cells deriving from condition 1, compared with untreated control cells (Fig. 2). Each point of the growth curves represented the mean of the observation recorded in 28 experimental replicates. It is evident the delay in the growth curves induced by the thermal treatment. Even more noticeable was the effect on the lag phase lasting of the thermal-treated cells in presence of the two terpenoids. In addition, the analysis of the standard deviation of all the reading points of the growth curves showed how the variability was dependent on the kind of antimicrobial treatment $\left(55^{\circ} \mathrm{C}\right.$ $\mathrm{TC}>55^{\circ} \mathrm{C}>$ Untreated). The data concerning the samples in which growth was observed were then modeled with the Gompertz equation, as modified by Zwietering et al. ${ }^{29}$. The measurement of the OD is an indirect method in which the absorbance changes occurs when the bacterial concentration reaches a minimum bacterial concentration of approx. $7 \mathrm{log}$ cells/ml, after which the OD linearly increases up to a concentration of 8 log cells/ $\mathrm{ml}$ reaching the higher absorbance allowed by the instrumental conditions $\mathrm{s}^{30}$. The parameter $\lambda$ of the model (lag phase duration) was used to estimate the time needed to obtain this critical threshold, i.e. necessary to have an increase of the $\mathrm{OD}_{600}$ baseline. Figure 3 reports the Box and Whisker plots regarding the $\lambda$ values estimated in the wells in which growth occurred. Independently of the inoculum, $\lambda$ increased, as expected, with the severity of the treatment. Noteworthy, also the variability of the responses increased with the stress applied. This variability was particularly relevant in the thermal treatment in the presence of terpenes, with the exception of inoculum 4 (inoculum from a liquid culture to fresh medium); however, in this latter case the data are affected by the presence of only $11 \%$ ( 3 out of 28 ) of positive cases. The lack of homoscedasticity of the variance did not allow the use of ANOVA to exploit the difference among the samples. Even after a log transformation of $\lambda$ the requisite was not accomplished (data not shown). For this reason, the non-parametric Kruskal-Wallis test ${ }^{31}$ was applied and the results are reported in Table 2. The result of this test showed a significant difference between the ranks of $\lambda$ and the treatments $(\mathrm{P}<0.001)$. Untreated samples were not significantly different with the exception of inoculum 1 (direct inoculation from colony to broth) which showed lower $\lambda$ values. Among the thermal treated samples, no differences were observed between inoculum 2 (direct inoculation from frozen stock) and 4 (inoculum from early stationary phase culture to fresh medium), which, however, showed respectively 79 and $50 \%$ of growth among the inoculated samples. Inoculum 1 and 3 (cold adapted cells), in which all the replicates grew, showed significantly lower $\lambda$ values. The samples added with thymol and carvacrol were grouped together, even if the samples from inoculum 4 did not present significant differences with the samples obtained from inoculum 2 and inoculum 4 thermally treated at $55^{\circ} \mathrm{C}$. Nevertheless, in this latter case, only in 3 out of 28 samples the growth was observed.

Recovery of L. monocytogenes cells in food model systems. Based on viability, culturability and recovery data, the cells deriving from inoculum 1 (direct inoculation of a colony in liquid medium and growth for $24 \mathrm{~h}$ ) resulted the more prompted to counteract the applied stress. To mimic the worst scenario, these cells were used to contaminate 2 different food matrices. The attention was focused on Gorgonzola cheese and sliced roast beef, which can be susceptible to L. monocytogenes colonization ${ }^{32,33}$. Both matrices were inoculated with non-treated (control) and treated cells $\left(55^{\circ} \mathrm{C}\right.$ and $55^{\circ} \mathrm{C}$ TC). The size of inoculum was around $4.6-4.8 \mathrm{log}$ cell/g 


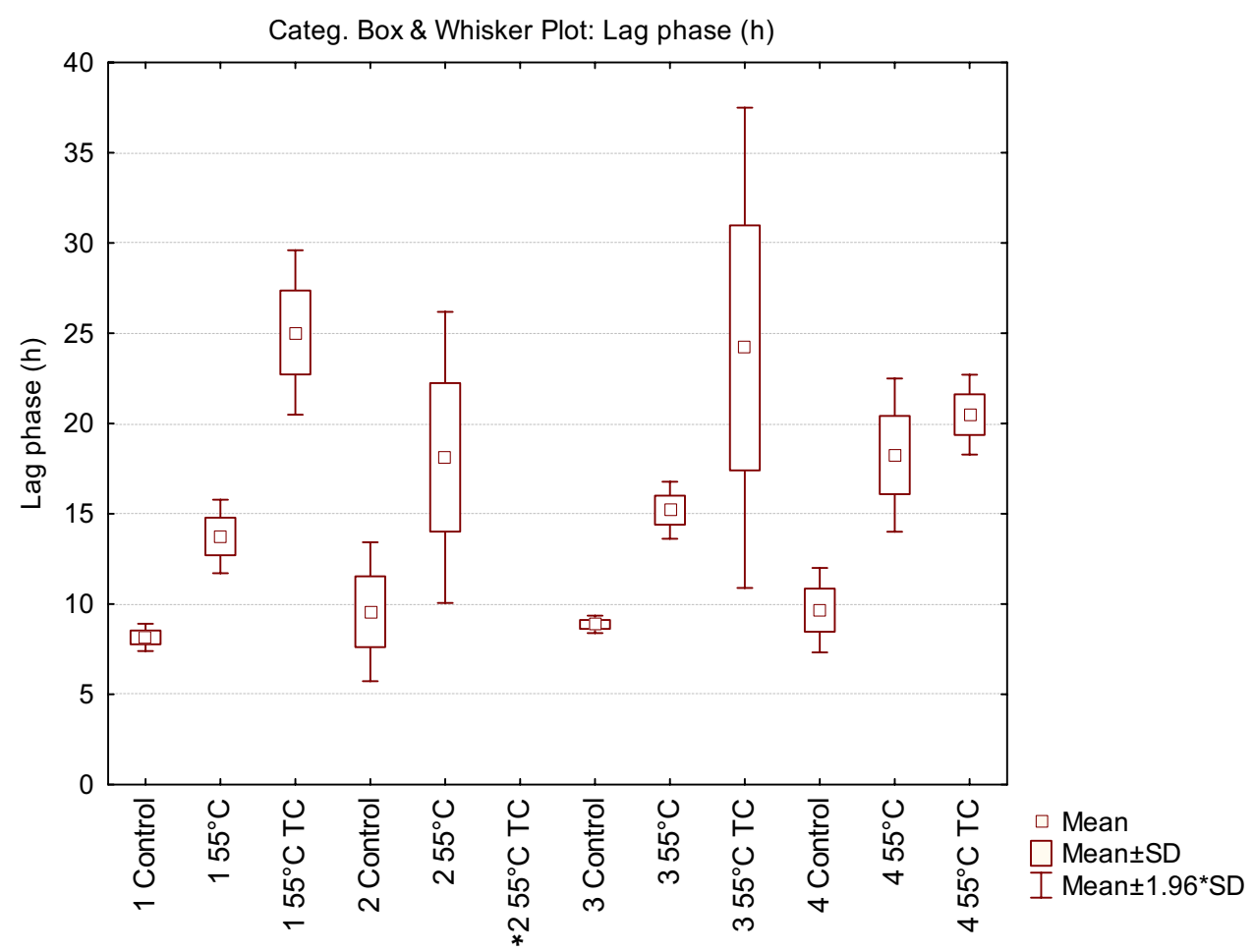

Figure 3. Box and Whisker plot describing the variability of lag phase $(\lambda)$ in relation to the different cell origin and treatment. In the condition marked by an asterisk no growth was observed in any of the 28 replicates.

\begin{tabular}{|l|l|l|l|l|l|l|l|l|l|l|}
\hline Cell origin & Treatment & Mean $^{\mathbf{a}}$ & $\mathbf{S D}^{\mathbf{b}}$ & $\mathbf{N}^{\mathrm{c}}$ & $\mathbf{M i n}^{\mathbf{d}}$ & Max $^{\mathrm{e}}$ & $\mathbf{Q 2 5}^{\mathrm{f}}$ & $\mathbf{Q 5 0}^{\mathrm{g}}$ & $\mathbf{Q 7 5}^{\mathrm{h}}$ & Groups $^{\mathbf{i}}$ \\
\hline 1 & Control & 8.16 & 0.38 & 28 & 7.27 & 8.69 & 7.84 & 8.36 & 8.41 & $\mathrm{a}$ \\
\hline 2 & Control & 9.58 & 1.96 & 28 & 7.53 & 11.73 & 7.70 & 9.31 & 11.60 & $\mathrm{~b}$ \\
\hline 3 & Control & 8.88 & 0.25 & 28 & 8.32 & 9.34 & 8.68 & 8.92 & 9.07 & $\mathrm{~b}$ \\
\hline 4 & Control & 9.66 & 1.16 & 28 & 7.78 & 10.93 & 8.56 & 10.19 & 10.77 & $\mathrm{~b}$ \\
\hline 1 & $55^{\circ} \mathrm{C}$ & 13.75 & 1.04 & 28 & 12.11 & 17.16 & 13.16 & 13.62 & 14.10 & $\mathrm{c}$ \\
\hline 2 & $55^{\circ} \mathrm{C}$ & 18.13 & 4.11 & 22 & 13.34 & 29.25 & 14.91 & 17.20 & 20.82 & $\mathrm{~d}$ \\
\hline 3 & $55^{\circ} \mathrm{C}$ & 15.20 & 0.81 & 28 & 13.22 & 16.41 & 14.62 & 15,023 & 15.88 & $\mathrm{e}$ \\
\hline 4 & $55^{\circ} \mathrm{C}$ & 18.25 & 2.17 & 14 & 11.78 & 20.84 & 17.76 & 18.64 & 19.46 & $\mathrm{~d}$ \\
\hline 1 & $55^{\circ} \mathrm{C} \mathrm{TC}$ & 25.05 & 2.32 & 28 & 20.97 & 30.50 & 23.68 & 24.92 & 26.23 & $\mathrm{f}$ \\
\hline 2 & $55^{\circ} \mathrm{C} \mathrm{TC}$ & - & - & 0 & - & - & - & - & - & - \\
\hline 3 & $55^{\circ} \mathrm{C} \mathrm{TC}$ & 24.19 & 6.79 & 12 & 15.90 & 37.81 & 20.30 & 20.96 & 27.53 & $\mathrm{f}$ \\
\hline 4 & $55^{\circ} \mathrm{C} \mathrm{TC}$ & 20.50 & 1.13 & 3 & 19.21 & 21.30 & 20.09 & 20.98 & 21.14 & fd \\
\hline
\end{tabular}

Table 2. Results of the application of the non-parametric Kruskal Wallis test to the lag phase $(\lambda)$ estimates in the different conditions. ${ }^{\mathrm{a}}$ Mean value for $\lambda .{ }^{\mathrm{b}}$ Standard Deviation. ${ }^{\mathrm{c}}$ Number of replicates in which growth was observed (out of 28 replicates). ${ }^{\mathrm{d}}$ Minimum $\lambda$ value observed. ${ }^{\mathrm{e}}$ Maximum $\lambda$ value observed. ${ }^{\mathrm{f}} 25$ th quartile. ${ }^{\mathrm{g}} 50$ th quartile (median). ${ }^{\mathrm{h}} 75$ th quartile. ${ }^{\mathrm{i}}$ Grouping of the treatments according to Kruskal Wallis test $(\mathrm{p}<0.01)$.

(50 $\mu \mathrm{l}$ of the original cell suspension in PBS) and after inoculation the samples were stored at $4{ }^{\circ} \mathrm{C}$, then analysed after 3 and 7 days of incubation. Microbiological analyses were carried out using plate counting as well as qPCR to determine culturability and the total L. monocytogenes cell counting, respectively. A non-inoculated sample was also considered to exclude the presence of L. monocytogenes in the raw materials. The results indicated that this pathogen was not detected, neither by cultivation nor molecular methods, in non-inoculated samples for both kind of foods (data not shown). Results concerning roast beef slices (Fig. 4A) showed that at T0 the counting in the control sample was $4.81 \mathrm{log} \mathrm{CFU} / \mathrm{g}$ (according to plate counting) and $4.61 \mathrm{log}$ cells/g (according to q-PCR). In the treated samples, the qPCR confirmed the same cell concentration, but the culturability decreased at $3.0 \log \mathrm{CFU} / \mathrm{g}$ in the thermal treated cells. The presence of terpenoids determined a higher decrease of the culturability (below $1 \log \mathrm{CFU} / \mathrm{g}$ ) since T0. However, treated cells were not able to recover their culturability after 3 and 7 days of incubation. Moreover, the total number of L. monocytogenes cells (qPCR data) remained 


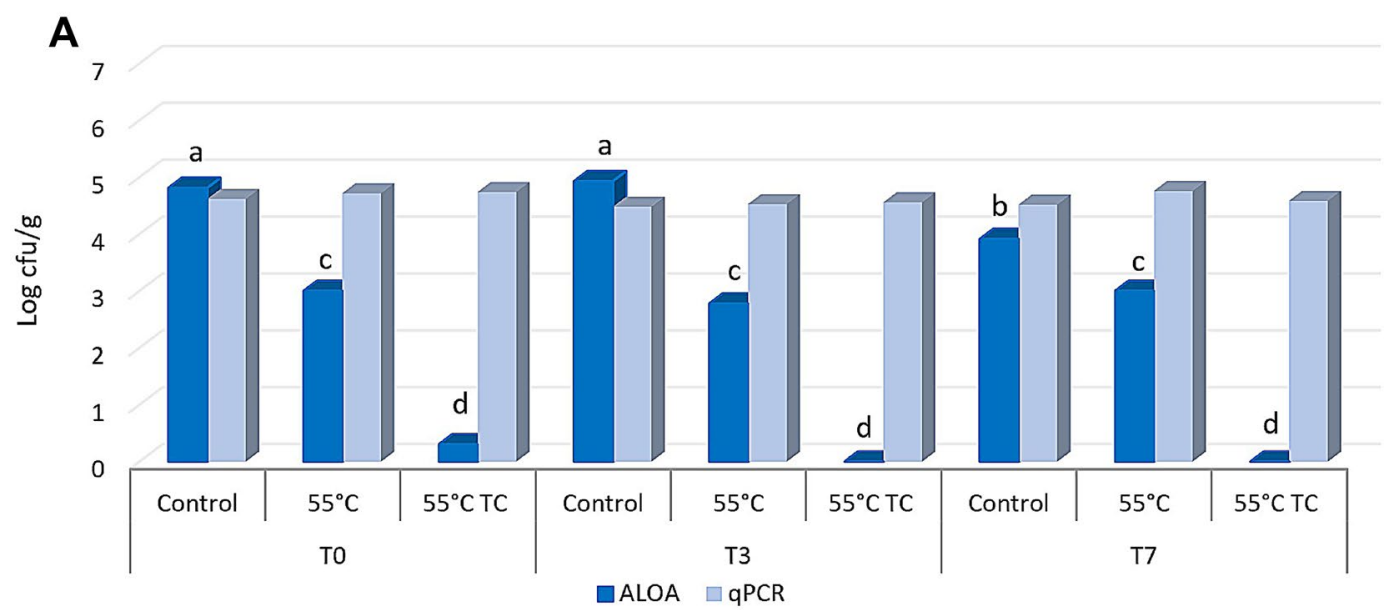

B

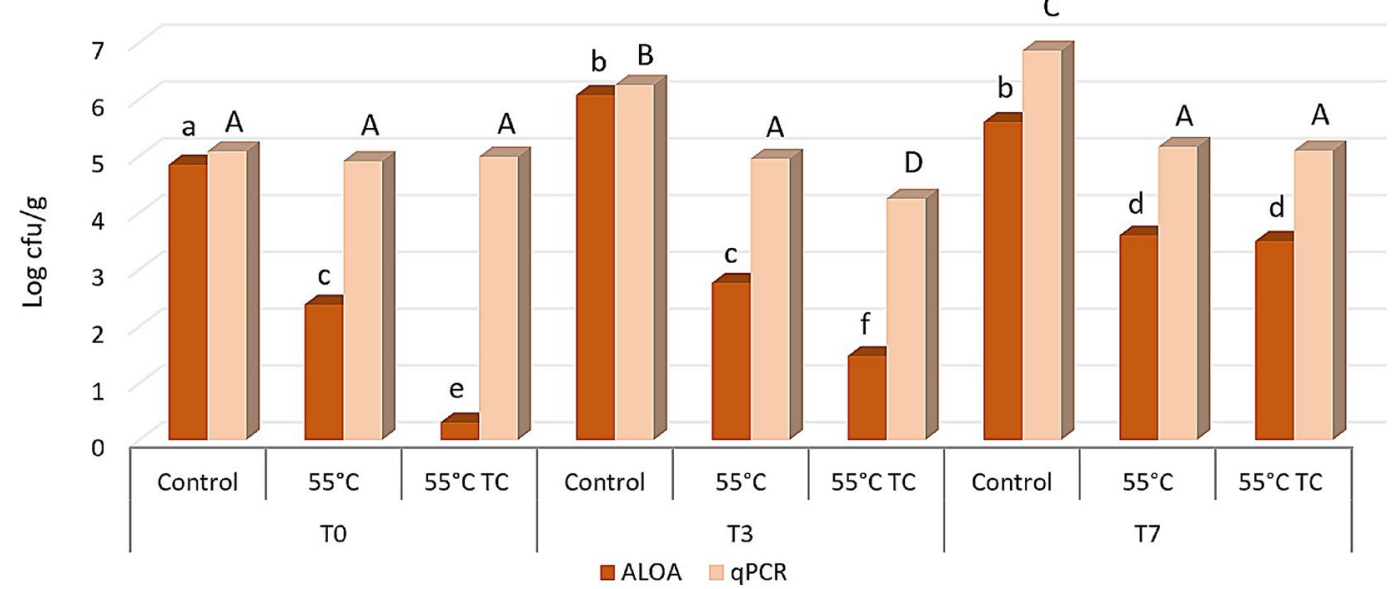

Figure 4. Culturability on ALOA and total L. monocytogenes cell counting by qPCR with species specific primer on roast beef slices (A) and Gorgonzola rind (B) stored at $4^{\circ} \mathrm{C}$ after contamination. Before the inoculum cells were not treated (Control), treated at $55^{\circ} \mathrm{C}\left(55^{\circ} \mathrm{C}\right)$ or treated at $55^{\circ} \mathrm{C}$ in the presence of thymol and carvacrol $\left(55^{\circ} \mathrm{C}\right.$ TC). Significant differences between samples according to ANOVA are indicated by lowercase letters for cell culturability and capital letters for cell counting by qPCR.

stable over the time and in all samples, including control cells. Our results are in accordance with Skjerdal et al. ${ }^{34}$, where authors did not find any growth when L. monocytogenes was inoculated in a challenge test on roast beef slices, confirming that roast beef is not an ideal substrate for the growth of the cells when stored at refrigerated temperatures.

A different scenario was observed when cells were inoculated on Gorgonzola rind (Fig. 4B). The initial quantifications at $\mathrm{T} 0$ were similar to those obtained for roast beef, both in terms of $\log \mathrm{CFU} / \mathrm{g}$ and total number of cells/g. Conversely to roast beef, control cells of L. monocytogenes were able to increase the total cell concentration after 3 days at $4{ }^{\circ} \mathrm{C}$ (T3) reaching values of about $6 \log$ cell/g (with both quantification methods). After 7 days, control cells reached up to $7 \log$ cell/g according to qPCR, while the culturability remained comparable to T3. Concerning heat treated cells, only a slight increase of the culturability was observed at T3 and T7, while the total number of cells detected by qPCR remained constant. Analogously, the total concentration of the heat treated cells in presence of terpens remained constant, while some of the cells reacquired their culturability after 3 (T3) and 7 (T7) days at $4{ }^{\circ} \mathrm{C}$ (Fig. 4B), reaching up to $3 \log \mathrm{CFU} / \mathrm{g}$. These results suggest that the increased values observed could be due to a resuscitation of VBNC cells rather than the cell ability to duplicate on Gorgonzola rind.

Differences among the two matrices can be explained by the competition between spiked cells of L. monocytogenes and the microorganisms naturally present on foods. This aspect was already underlined by Broady et al ${ }^{33}$ which observed the inability of L. monocytogenes to grow, even if inoculated, in some roast beef samples. McDonnell et al ${ }^{35}$ observed a lower growth of this pathogen in roast beef if compared with other meat product, and a $2 \log \mathrm{cfu} / \mathrm{g}$ cell increase required 4 weeks at $4^{\circ} \mathrm{C}$. On the other side, blue veined cheeses such as Gorgonzola, are favorable substrates for L. monocytogenes ${ }^{32,36}$ and lactic acid bacteria, which dominate the microbiota, show limited anti-listerial activity, especially if the contamination takes places after the ripening period ${ }^{37}$. 


\section{Conclusions}

L. monocytogenes is a concern in the food industry and several methods to prevent its replication on foods are being investigated. Among them, the combination of mild heat treatment and natural antimicrobials as terpenoids thymol and carvacrol resulted in a synergistic effect for a partial or total inactivation of L. monocytogenes ${ }^{6}$. However, the connection between the inoculation method and the effectiveness of the antimicrobial treatment has never been explored in this foodborne pathogen. Moreover, the ability of the viable but not culturable cells to recover their ability to replicate remains a dark point which needs clarification.

In our study we highlighted for the first time a link between the origin of the cells and the sensitivity towards an antimicrobial treatment in L. monocytogenes. Here, we found that cells from inoculation method 1 (from colony to BHI broth) resulted less sensitive to the thermal treatment combined with terpenoids. This finding could indicate that the physiological state of the cells is a determinant for effectiveness of the treatment. Indeed, both culturability and viability were differently affected by the antimicrobial treatment depending on the inoculation method. The effectiveness of a treatment is in general assessed by standard laboratory culture techniques, that do not allow the detection of VBNC cells. This state is induced by environmental stress $(\mathrm{pH}$, temperature, thermal stress, antimicrobials $)^{27}$. Therefore, the common laboratory practice may lead to an overestimation of the efficacy of the treatment. In this context, flow cytometry represents a good strategy that can be integrated with classical plate counting, because it allows to reveal not only viable cells, but injured and dead cells as well. The VBNC population, for definition, is non culturable and it can represent a risk for producer and consumer. Indeed, this part of the population can resuscitate under favorable conditions and recover the ability to duplicate. In our study, the recovery ability was assessed both in vitro (in BHI broth) and in vivo (Gorgonzola rind and roast beef). Although only preliminary results, our data confirmed that heat treated cells were able to partial recover their culturability in synthetic medium and when inoculated on Gorgonzola rind as well, likely due to a higher availability of nutrients and other factors intrinsic to this food matrix ( $\mathrm{pH}$, water activity, relative humidity).

In conclusion, our results stressed the importance of the cells history in the effectiveness of the antimicrobial treatment and the relevance to determine a common protocol for antimicrobial sensitivity assessment, to obtain comparable results among different laboratories. Although the reason of this effect needs further investigations, differences in cell history can strongly impact the outcomes of the assays, therefore raising safety concerns for health's consumer.

\section{Materials and methods}

Bacterial strains and culture conditions. The strain used in this study was L. monocytogenes Scott A belonging to the collection of the Department of Agricultural and Food Sciences (University of Bologna). The strain was maintained as glycerol $(20 \% \mathrm{v} / \mathrm{v})$ stock at $-80^{\circ} \mathrm{C}$ (condition 2 , Fig. 1). The strain was pre-cultured in Brain Heart Infusion (BHI; Oxoid, UK) for $24 \mathrm{~h}$ at $37^{\circ} \mathrm{C}$ at $200 \mathrm{rpm}$-shaking conditions (Heidolph, Germany). Part of these cells were then used to inoculate (i) a BHI agar plate to obtain a single colony for a new flask inoculation (conditions 1 and 3, Fig. 1) and (ii) a new flask of BHI (condition 4, Fig. 1). Cold adapted cells of condition 3 were kept at $4{ }^{\circ} \mathrm{C}$ in a flak. Cells from condition 1 to 4 were used to investigate the effect of the cell origin on the response of this strains to thermal treatment combined or not with terpenoids (thymol and carvacrol). Each condition was tested in triplicate.

Effect of thermal treatments and aroma compounds on the viability of L. monocytogenes. Cells deriving from the different pre-cultures were resuspended at a cell load of approx. $6 \mathrm{log}$ viable cells/ml (or Active Fluorescent Unit, AFU, determined by flow cytometry, see "Flow cytometric analysis") in sterile PBS (NaCl $9 \mathrm{~g} / \mathrm{l}$, $\mathrm{Na}_{2} \mathrm{HPO}_{4} 0.421 \mathrm{~g} / \mathrm{l}, \mathrm{KH}_{2} \mathrm{PO}_{4} 0.144 \mathrm{~g} / \mathrm{l}, \mathrm{pH} 7.4$ ), pre-heated at $55^{\circ} \mathrm{C}$ in a water bath LAUDA Ecoline (LAUDABrinkmann, LP., Delran, New Jersey, US). Isothermal treatments at $55^{\circ} \mathrm{C}$ for 30 min were performed in $50 \mathrm{ml}$ sterile tubes with or without the addition of terpenes. Particularly thymol and carvacrol (both provided by Sigma-Aldrich, St. Louis, MO) were previously dissolved in ethanol and then added just before inoculum at a concentration of $50 \mathrm{mg} / \mathrm{l}$ each. These concentrations were chosen based on the results obtained in a previous study ${ }^{6}$ and were below the MIC values (20 and 25\% of MIC for thymol and carvacrol, respectively) to not significantly affect per se cell culturability and viability. As control, we used a cell suspension treated with $0.5 \%$ (v/v) ethanol ${ }^{6}$.

Samples were collected at the end of the different treatments to evaluate: (i) cell culturability through plate counting onto $\mathrm{BHI}$ agar, by diluting cells suspension in $\mathrm{PBS}$ ( $\mathrm{pH} 7.4$ ), and incubation at $37^{\circ} \mathrm{C}$ for 24 to $48 \mathrm{~h}$; (ii) cell viability through flow cytometry (see "Flow cytometric analysis"); (iii) cell recovery in BHI broth at $37^{\circ} \mathrm{C}$. For this latter, the treated cell suspensions were inoculated 1:100 in fresh BHI in a 96 well plates (28 wells for each condition) through an automatic liquid handling system (EpMotion, Eppendorf, Italy) in a final volume of $200 \mu \mathrm{l} /$ well. Then microplates were incubated at $37^{\circ} \mathrm{C}$ for $48 \mathrm{~h}$ and cell growth was monitored using a spectrophotometer EON (Biotek, Winoosky, VT) programmed for readings (OD $600 \mathrm{~nm}$ ) every $15 \mathrm{~min}$.

Flow cytometry analysis. Cell suspensions collected after each treatment were analysed by flow cytometry using an Accuri C6 Plus flow cytometer (BD Biosciences, Milan, Italy). Setting parameters, emission filters and thresholds were defined according to Arioli et al. ${ }^{6}$. The cell suspensions were stained in the dark for 15 min at $37^{\circ} \mathrm{C}$ with $1 \mu \mathrm{M}$ SYTO $24^{\mathrm{m}}$ (ThermoFisher Scientific, Milan, Italy) and $2 \mu \mathrm{M}$ Propidium Iodide (Merck, Italy). SYTO $24^{\text {ts }}$ permeates the membrane of total cells and stains the nucleic acids with green fluorescence; PI penetrates only bacteria with damaged membranes, causing a reduction in SYTO $24^{\mathrm{Tn}}$ green fluorescence when both dyes are present. This dual staining allowed to distinguish three sub-populations: Active Fluorescent Unit (AFU, considered as alive cells), injured cells and non-Active Fluorescent Unit (non-AFU, considered as dead cells) ${ }^{38}$. 
Growth modeling. The data obtained from cell recovery, in which L. monocytogenes cells after the different treatments were inoculated in fresh BHI medium (initial concentration $4 \mathrm{log} \mathrm{cfu} / \mathrm{ml}$ ) and monitored for $48 \mathrm{~h}$ through the variation of optical density at $600 \mathrm{~nm}\left(\mathrm{OD}_{600}\right)$, were modeled with Gompertz equation as modified by Zwietering et al. ${ }^{28}$.

$$
y=A e^{-e^{\left[\left(\frac{\mu_{\max e}}{A}\right)(\lambda-t)+1\right]}}
$$

where $y$ is the $\mathrm{OD}_{600}$ at time $\mathrm{t}, A$ represents the maximum $\mathrm{OD}_{600}$ value reached, $\mu_{\max }$ is the maximum $\mathrm{OD}_{600}$ increase rate and $\lambda$ is the lag time.

L. monocytogenes cell recovery evaluation in food systems. The recovery ability of treated L. monocytogenes cells on food system was assessed by qPCR and by standard dilution and plating. The selected matrices were Gorgonzola cheese and roast beef, bought in a local supermarket. The cheese was sold as a slice contained in a hard-plastic packaging while the roast beef was thinly sliced and sold over the counter and is a common ready-to-eat meat in Italy. For the total quantification by a culture-independent method, standard curves were constructed from serially diluted cells of L. monocytogenes inoculated onto the food matrix. Gorgonzola cheese rind and roast beef slices were cut into pieces of $1 \mathrm{~g}$, then placed in a sterile Petri dish where they were inoculated on their surface with $50 \mu \mathrm{l}$ of cell suspension containing from $10^{4}$ up to $10^{7}$ cells/g. After the liquid had been adsorbed, we proceeded with the DNA extraction protocol (see "DNA extraction from food samples and qPCR analysis") and subsequent qPCR analysis. Standard curve was constructed by plotting the threshold cycle $\left(C_{T}\right)$ values obtained against the log number cells. The data obtained were expressed as cell number per gram of food matrix. The spiking of a food matrix with treated cells suspensions was carried out as follows. An overnight culture of L. monocytogenes was prepared and used in thermal treatment in presence or not of terpenoids (see protocol in "Effect of thermal treatments and aroma compounds on the viability of L. monocytogenes"). The treated cell suspensions were then used to spike Gorgonzola rind cube or roast beef strips that had been prepared in the same manner as the ones used to establish the standard curves. The suspensions used were: (i) non-treated cells (positive control), (ii) thermally treated cells at $55^{\circ} \mathrm{C}$ for $30 \mathrm{~min}$; (iii) thermally treated cells at $55^{\circ} \mathrm{C}$ for $30 \mathrm{~min}$ in presence of $50 \mathrm{mg} / \mathrm{l}$ of each terpenoid, (iv) only PBS (as negative control). After inoculation of the food matrix, samples were stored at $4{ }^{\circ} \mathrm{C}$ for 3 and 7 days. All the samples were subjected to analysis for total and culturable L. monocytogenes load determination on ALOA agar medium (Biolife, Italy). The analyses were performed in triplicate.

DNA extraction from food samples and qPCR analysis. The DNA from food matrixes (250 mg) was extracted by using DNeasy ${ }^{\oplus}$ PowerLyzer $^{\circledR}$ PowerSoil $^{\circledR}$ (Qiagen, Italy) according to manufacturer's protocol. Mechanical lysis of cells was carried out using a bead beater (Precellys 24, Bertin Technologies, Montigny le Bretonneux, France). The DNA extracted from food samples was quantified by using a NanoDrop (BioTek Instruments, Inc., CA, United States). Finally, the DNA was stored at $-80^{\circ} \mathrm{C}$ until molecular analysis. Real-time quantitative PCR (qPCR) protocols were adopted for the quantification of L. monocytogenes in food metagenomic DNA, targeting bile salt hydrolases gene $b s h$, bshF: GGCCTTAGTATGGCAGGACTCA and bshR: CTC ATTGTCCTTACCTTCTGCAAA ${ }^{39}$.

The amplification reaction was carried out in a final volume of $15 \mathrm{ml}$ containing $7.5 \mathrm{ml}$ of EvaGreen.

R Supermix (Bio-Rad Laboratories, Segrate, Italy) and $0.5 \mathrm{mM}$ of each primer; $50 \mathrm{ng}$ of template DNA samples was used in each reaction. The amplification was carried out using the following thermal program: $95^{\circ} \mathrm{C} / 3 \mathrm{~min}$; $\left(95^{\circ} \mathrm{C} / 10 \mathrm{~s}, 63^{\circ} \mathrm{C} / 30 \mathrm{~s}, 72^{\circ} \mathrm{C} / 5 \mathrm{~s}\right) \times 39$ times. The standard curve was obtained by plotting the average Cq values versus $\log 10$ of the number of cells added to each food sample. Melting curves were analysed with Bio-Rad CFX Manager 3.1 software to confirm the specificity of the amplification products.

The cell culturability was assessed by diluting $1 \mathrm{~g}$-Gorgonzola rind or roast beef slice in PBS (pH 7.4) and plating on ALOA (Biolife, Milan, Italy) for the discrimination and counting of L. monocytogenes cells.

Statistical analysis. To assess the sensitivity of L. monocytogenes to thermal treatments and aroma compounds, three independent experiments were carried out. The data were statistically analysed using the one-way ANOVA. The Tukey critical difference test was performed to determine differences among different conditions $(p<0.05)$. The parameters of the Gompertz equation were estimated by non-linear regression. The presence of significative differences among the $\lambda$ estimates was evaluated by using the non-parametric Kruskal Wallis test $(\mathrm{p}<0.01)$. Statistica for Windows 6.1 package was used for analyses (Statsoft Italia, Vigonza, Italy).

Received: 25 May 2021; Accepted: 11 October 2021

Published online: 28 October 2021

\section{References}

1. Ryser, E. T. \& Buchanan, R. L. Listeria monocytogenes. In Food Microbiology: Fundamentals and Frontiers (eds Doyle, M. P. \& Buchanan, R. L.) 503-545 (ASM Press, 2013).

2. Buchanan, R. L., Gorris, L. G. M., Hayman, M. M., Jackson, T. C. \& Whiting, R. C. A review of Listeria monocytogenes: An update on outbreaks, virulence, dose-response, ecology, and risk assessments. Food Control 75, 1-13 (2017).

3. ANSES: French Agency for Food, Environmental and Occupational Health \& Safety. Data sheet on foodborne biological hazards: Listeria monocytogenes (2012). https://www.anses.fr/en/system/files/MIC2011sa0171FiEN.pdf. Accessed 12 Aug 2020.

4. Bahrami, A., Baboli, Z. M., Schimmel, K., Jafari, S. M. \& Williams, L. Efficiency of novel processing technologies for the control of Listeria monocytogenes in food products. Trends Food Sci. Technol. 96, 61-78 (2020). 
5. Rachon, G., Penaloza, W. \& Gibbs, P. A. Inactivation of Salmonella, Listeria monocytogenes and Enterococcus faecium NRRLB-2354 in a selection of low moisture foods. Int. J. Food Microbiol. 231, 16-25 (2016).

6. Arioli, S. et al. Modelling of Listeria monocytogenes Scott A after a mild heat treatment in the presence of thymol and carvacrol: Effects on culturability and viability. J. Food Eng. 240, 73-82 (2019).

7. Cava-Roda, R. M., Taboada, A., Palop, A., López-Gómez, A. \& Marin-Iniesta, F. Heat resistance of Listeria monocytogenes in semi-skim milk supplemented with vanillin. Int. J. Food Microbiol. 157, 314-318 (2012).

8. Char, C., Guerrero, S. \& Alzamora, S. M. Survival of Listeria innocua in thermally processed orange juice as affected by vanillin addition. Food Control 20, 67-74 (2009).

9. Guevara, L., Antolinos, V., Palop, A. \& Periago, P. M. Impact of moderate heat, carvacrol, and thymol treatments on the viability, injury, and stress response of Listeria monocytogenes. BioMed Res. Int. 2015, 548930 (2015).

10. Karatzas, A. K., Bennik, M. H. J., Smid, E. J. \& Kets, E. P. W. Combined action of S-carvone and mild heat treatment on Listeria monocytogenes Scott A. J. Appl. Microbiol. 89, 296-301 (2000).

11. Sado-Kamdem, S. S., Belletti, N., Magnani, R., Lanciotti, R. \& Gardini, F. Effects of carvacrol, (E)-2-hexenal, and citral on the thermal death kinetics of Listeria monocytogenes. J. Food Prot. 74, 2070-2078 (2011).

12. Gurtler, J. B., Fan, X. T., Jin, T. \& Niemira, B. A. Influence of antimicrobial agents on the thermal sensitivity of foodborne pathogens: A review. J. Food Prot. 82, 628-644 (2019).

13. Lanciotti, R. et al. Use of natural aroma compounds to improve shelf life and safety of minimally processed fruits. Trends Food Sci. Technol. 15, 201-208 (2004).

14. den Besten, H. M. W., Wells-Bennik, M. H. J. \& Zwietering, M. H. Natural diversity in heat resistance of bacteria and bacterial spores: Impact on food safety and quality. Annu. Rev. Food Sci. Technol. 9, 383-410 (2018).

15. Kragh, K. N. et al. The inoculation method could impact the outcome of microbiological experiments. Appl. Environ. Microbiol. 84, e02264-e2317 (2018).

16. Augustin, J. C. et al. Design of challenge testing experiments to assess the variability of Listeria monocytogenes growth in foods. Food Microbiol. 28, 746-754 (2011).

17. Aryani, D. C., den Besten, H. M., Hazeleger, W. C. \& Zwietering, M. H. Quantifying variability on thermal resistance of Listeria monocytogenes. Int. J. Food Microbiol. 193, 130-138 (2015).

18. Luidalepp, H., Joers, A., Kaldalu, N. \& Tenson, T. Age of inoculum strongly influences persister frequency and can mask effects of mutations implicated in altered persistence. J. Bacteriol. 193, 3598-3605 (2011).

19. Savijoki, K. et al. Growth mode and physiological state of cells prior to biofilm formation affect immune evasion and persistence of Staphylococcus aureus. Microorganisms 8, 106 (2020).

20. Hayman, M. H., Anantheswaran, R. C. \& Knabel, S. J. The effects of growth temperature and growth phase on the inactivation of Listeria monocytogenes in whole milk subject to high pressure processing. Int. J. Food Microbiol. 115, 220-226 (2007).

21. Romick, T. L., Fleming, H. P. \& McFeeters, R. F. Aerobic and anaerobic metabolism of Listeria monocytogenes in defined glucose medium. Appl. Environ. Microbiol. 62, 304-307 (1996).

22. Roberts, B. N., Chakravarty, D., Gardner, J. C. III. \& Ricke, S. C. Listeria monocytogenes response to anaerobic environments. Pathogens 9, 210 (2020).

23. Donnelly, C. W. \& Diez-Gonzalez, F. Listeria monocytogenes. In Guide to Foodborne Pathogens (eds Labbé, R. G. \& García, S.) 45-74 (Wiley, 2013).

24. Alessandria, V., Rantsiou, K., Cavallero, M. C. \& Cocolin, L. S. Effect of atmospheric pressure plasma on Listeria monocytogenes attached to abiotic surfaces. J. Food Prot. 82, 233-237 (2019).

25. Zhang, S., Ye, C., Lin, H., Lv, L. \& Yu, X. UV disinfection induces a VBNC state in Escherichia coli and Pseudomonas aeruginosa. Environ. Sci. Technol. 49, 1721-1728 (2015).

26. Noll, M. et al. Benzalkonium chloride induces a VBNC state in Listeria monocytogenes. Microorganisms 8, 184 (2020).

27. Gu, G. et al. Susceptibility of foodborne pathogens to sanitizers in produce rinse water and potential induction of viable but nonculturable state. Food Control 112, 107-138 (2020).

28. Highmore, C. J., Warner, J. C., Rothwell, S. D., Wilks, S. A. \& Keevil, C. W. Viable-but-nonculturable Listeria monocytogenes and Salmonella enterica serovar Thompson induced by chlorine stress remain infectious. MBio 9, 2 (2018).

29. Zwietering, M. H., Jongenburger, I., Rombouts, F. M. \& van't Riet, K. Modeling of the bacterial growth curve. Appl. Environ. Microbiol. 56, 1875-1881 (1990).

30. Rasch, M. Experimental design and data collection. In Modeling Microbial Responses in Food (eds McKellar, R. C. \& Lu, X.) 1-20 (CRC Press, 2004).

31. Granato, D., de Araújo Calado, V. M. \& Jarvis, B. Observations on the use of statistical methods in food science and technology. Food Res. Int. 55, 137-149 (2014).

32. Bernini, V. et al. Cutting procedures might be responsible for Listeria monocytogenes contamination of foods: The case of Gorgonzola cheese. Food Control 61, 54-61 (2016).

33. Broady, J. W. et al. Survival and metabolic activity of Listeria monocytogenes on ready-to-eat roast beef stored at 4 degrees C. J. Food Sci. 81, M1766-M1772 (2016).

34. Skjerdal, T. et al. Development and validation of a regression model for Listeria monocytogenes growth in roast beefs. Food Microbiol. 98, 103770 (2021).

35. McDonnell, L. M., Glass, K. A. \& Sindelar, J. J. Identifying ingredients that delay outgrowth of Listeria monocytogenes in natural, organic, and clean-label ready-to-eat meat and poultry products. J. Food Prot. 76, 1366-1376 (2013).

36. Mucchetti, G. \& Neviani, E. Microbiologia e Tecnologia Lattiero-Casearia Qualità e Sicurezza 1st edn. (Tecniche Nuove, 2006).

37. Morandi, S., Silvetti, T., Battelli, G. \& Brasca, M. Can lactic acid bacteria be an efficient tool for controlling Listeria monocytogenes contamination on cheese surface? The case of Gorgonzola cheese. Food Control 96, 499-507 (2019).

38. Muñoz, M., Guevara, L., Palop, A., Tabera, J. \& Fernández, P. S. Determination of the effect of plant essential oils obtained by supercritical fluid extraction on the growth and viability of Listeria monocytogenes in broth and food systems using flow cytometry. LWT Food Sci. Technol. 42, 220-227 (2009).

39. Braschi, G. et al. Gene expression responses of Listeria monocytogenes Scott A exposed to sub-lethal concentrations of natural antimicrobials. Int. J. Food Microbiol. 286, 170-178 (2018).

\section{Acknowledgements}

This study was partially supported by a grant of the Italian Society of Agricultural, Food and Environmental Microbiology (SIMTREA) assigned to CM and SA, to support and encourage knowledge exchange among young researchers. The Department of Food, Environmental and Nutritional Sciences, Università degli Studi di Milano, partially covered the open access APC. 


\section{Author contributions}

C.M. and S.A. conceived the experiments. C.M., R.D., G.T., and F.B. carried out the experiments. C.M., R.D., G.T., F.B., and S.A. analysed the data. C.M. and S.A. wrote the manuscript. D.M. and F.G. reviewed the manuscript. All co-authors commented the manuscript.

\section{Competing interests}

The authors declare no competing interests.

\section{Additional information}

Correspondence and requests for materials should be addressed to S.A.

Reprints and permissions information is available at www.nature.com/reprints.

Publisher's note Springer Nature remains neutral with regard to jurisdictional claims in published maps and institutional affiliations.

(c) (i) Open Access This article is licensed under a Creative Commons Attribution 4.0 International License, which permits use, sharing, adaptation, distribution and reproduction in any medium or format, as long as you give appropriate credit to the original author(s) and the source, provide a link to the Creative Commons licence, and indicate if changes were made. The images or other third party material in this article are included in the article's Creative Commons licence, unless indicated otherwise in a credit line to the material. If material is not included in the article's Creative Commons licence and your intended use is not permitted by statutory regulation or exceeds the permitted use, you will need to obtain permission directly from the copyright holder. To view a copy of this licence, visit http://creativecommons.org/licenses/by/4.0/.

(C) The Author(s) 2021, corrected publication 2022 